\title{
ENHANCING THE EFFICIENCY OF ZINC PHOSPHIDE BAIT USING ANTISPASMODIC AGENT(OCTYLONIUM BROMIDE) AGAINST ALBINO AND WILD NORWAY RATS
}

\author{
GABR, W. M. AND A. M. RIZK
}

Plant Protection Research Institute, ARC, Dokki, Giza

(Manuscript received 17 Janaury 2010)

\section{Abstract}

Laboratory and field trials were conducted to enhance the efficiency of zinc phosphide bait against rats using Spasmomen drug (octylonium bromide) as an antispasmodic agent. Spasmomen was tested alone and mixed with zinc phosphide bait at different concentrations using non and free choice feeding methods against albino rat and wild Norway rat, Rattus norvegicus. Results indicated that Spasmomen at rate $0.05 \%$ when added to zinc phosphide bait at level 0.25 and $0.125 \%$ achieved 43.5 and $46.3 \%$ acceptance, respectively and enhanced the mortality from 50 to $75 \%$. The field performance was in harmony with laboratory results as Spasmomen enhanced the population reduction percentage of Norway rat from 17.4 to $56.0 \%$ and from 66.0 to $71.2 \%$ when added to zinc phosphide bait 0.125 and $0.25 \%$, respectively. The antispasmodic action of Spasmomen prevent the pain resulting from zinc phosphide treatment. This action lead rats to accept the bait of zinc phosphide and eat more causing high mortality percentage.

Key words: Zinc phosphide - Antispasmodic agent - Norway rat.

\section{INTRODUCTION}

Zinc phosphide is an important rodenticide, since it is effective against rats and mice, rather cheep, locally produced and is an acute poison with a quick mode of action. It is especially useful for the rapid reduction of large population of rodents. Also, zinc phosphide is probably the acute poison of choice when anticoagulant cannot be used or are not available. Bait shyness is the major drawback in using zinc phosphide against different rodent species (Meehan, 1984). The consumption of a small quantity of zinc phosphide $\left(1 / 4 L_{50}\right)$ at the first time, is likely to be sufficient to elicit unpleasant symptoms but not to cause death. The fast onset of toxicsis enables rodents then to associate cause and effect. Affected animals will usually refuse to consume the poisoned food on subsequent occasions or may be reluctant to feed again from bait receptacles (Prakash, 1988).

The present study was an attempt to overcome bait shyness phenomenon using antispasmodic agent to prevent the pain resulting from zinc phosphide treatment under laboratory and field conditions. 
442 ENHANCING THE EFFICIENCY OF ZINC PHOSPHIDE BAIT USING ANTISPASMODIC AGENT

(OCTYLONIUM BROMIDE) AGAINST ALBINO AND WILD NORWAY RATS

\section{MATERIALS AND METHODS}

\section{1- Tested Compounds}

1-1- Zinc phosphide $94 \%\left(\mathrm{Zn}_{3} \mathrm{P}_{2}\right)$ is an acute rodenticides obtained from $\mathrm{KZ}$ Company. It was used as a bait at rate of $0.5,0.25,0.125$ and $0.0625 \%$ mixed with crushed maize.

1-2- Spasmomen drug (octylonium bromide $40 \mathrm{mg}$ ), p-[2-(n-octyloxy)-benzoyl]aminobenzoate of $\mathrm{N}$-diethyl-methyl- ammonium- ethyl bromide. It is an antispasmodic agent in the treatment of spastic states and gastrointestinal tract spasm. It was obtained from Minapharm Co., as tablets each of $40 \mathrm{mg}$. It was powdered and used at 0.1 and $0.05 \%$ mixed with crushed maize or added to zinc phosphide bait.

\section{2- Tested Animais}

The adult individuals of albino rat, Rattus norvegicus (Berk.) were used for laboratory experiments. Animals were caged individually and fed on a free diet and water. The unhealthy and pregnant animals were excluded. Animals were weighed and given a reference number for each one. The field experiments were conducted on the wild Norway rat, Rattus norvegicus, which was the dominant species in drainage canal, El-Wasta district, Beni- Suef Governorate.

\section{3- Laboratory Experiments}

Different concentrations of zinc phosphide bait were tested alone and mixed with Spasmomen drug using non and free choice feeding methods.

\section{3-1- Non Choice Feeding Method}

\section{3-1-1- Zinc Phosphide Treatment}

Four different concentrations of zinc phosphide bait i.e. $0.5,0.25,0.125$ and $0.0625 \%$ were tested against albino rat Rattus norvegicus. Animals were divided into 4 groups ( each of 8 rats ). One group for each tested concentration and another one as a check control. Each animal was offered $20 \mathrm{~g}$ of zinc phosphide bait for $24 \mathrm{~h}$, then replaced by untreated bait. The consumed amount of bait was daily calculated. The clinical symptoms of poisoning on animals were observed. Mortality and time to death were recorded.

\section{3-1-2- Spasmomen Treatment}

Two concentrations of Spasmomen was tested alone and added to zinc phosphide bait against albino rat. Animals were divided into 6 groups (each of 8 animals) for treatments and another one for control. The six treatments were: Spasmomen 0.1 and $0.05 \%$, combination of Spasmomen $0.1 \%+$ zinc phosphide $0.25 \%$, mixture of Spasmomen $0.1+$ zinc ph. $0.125 \%$, Spasmomen $0.05 \%+$ zinc ph. $0.125 \%$ and Spasmomen $0.05 \%+$ zinc ph. $0.125 \%$. Fifty grams of bait were offered to each rat for 4 successive days. The consumed amount of bait was daily estimated 
and the clinical symptoms of poisoning were observed. Mortality percentage and time to death were recorded

\section{3-2-Free Choice Feeding Method}

Free choice feeding test is important to determine the acceptability of the tested compound (Gabr et al., 2004) by comparing its consumption with that of standard challenge diet $(65 \%$ crushed maize $+25 \%$ ground wheat $+5 \%$ sugar $+5 \%$ corn oil ) according to Palmateer (1974). Animals were divided into 6 groups (8 animals of each). One group for each treatment and another one as a control. One of the tested baits (Spasmomen alone at 0.1 and $0.5 \%$ zinc phosphide alone at 0.25 and $0.125 \%$ and mixture of the two compounds) and challenge diet were offered to each animal ( $50 \mathrm{~g}$ of each) in small separate dishes. Their position was daily altered to avoid feeding preference for a certain location. The consumed amount of bait and diet was recorded daily for 4 successive days. The same previous proceeding was followed. A check control test was conducted using standard diet. Bait acceptance was recorded as follows:

$$
\text { Acceptance } \%=\frac{\text { Consumed amount of treated bait }}{\text { Consumed amount of treated bait }+ \text { Callenge diet }} \times 100
$$

\section{4- Field Experiments}

Evaluation of different concentrations zinc phosphide bait alone and mixed with Spasmomen drug was carried out under field conditions of El- Wasta district, BeniSuef Governorate. An area infested with Norway rat, Rattus norvegicus, was chosen and divided into distances (each of $200 \mathrm{~m}$ ) represents the number of treatments and another one was left without treatment as a check control. The population density of rats was estimated pre and post treatment using food consumption method (Rennison, 1977). Twenty five plastic sacks (each of $20 \mathrm{~g}$ ) for each treatment were distributed in the infested spots beside rat burrows for $48 \mathrm{hrs}$. The consumed amount of each treatment was recorded and the percentage of population reduction was calculated as follows:

Population reduction $\%=$

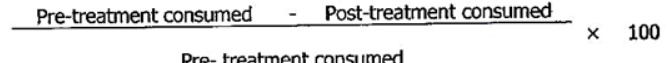

\section{RESULTS AND DISCUSSION}

\section{1- Laboratory Studies}

\section{1-1 Non- Choice Feeding Test}

The effect of different concentrations of zinc phosphide bait against albino rat was shown in Table (1). Data indicate that the average bait consumption increased with the decrease of the concentration of zinc phosphide as $0.5,0.25,0.125$ and 
$0.0625 \%$ concentration gave $4.1,4.3,4.8$ and $5.0 \mathrm{~g}$, respectively. Both concentrations of 0.5 and $0.25 \%$ achieved complete mortality $100 \%$. The concentration of $0.125 \%$ caused only $50 \%$ mortality while the lowest concentration $0.0625 \%$ fail to achieve any mortality percentage. Regarding the time required to death, it longed with reducing zinc phosphide concentration whereas it was 9,15 and $18 \mathrm{~h}$ for the three tested concentrations $0.5,0.25$ and $0.125 \%$. consecutively. Data in Table (2) showed the response of albino rat to zinc phosphide bait mixed with Spasmomen drug under nonchoice conditions. Results revealed that zinc phosphide bait $0.25 \%$ when mixed with Spasmomen 0.1 or $0.05 \%$ induced $100 \%$ mortality with 6.7 and $7.0 \mathrm{~g}$ average bait intake, respectively. The time required to death was shorter in case of Spasmomen $0.1 \%$ than $0.05 \%$ as it was $9 \mathrm{~h}$ with range $6-12 \mathrm{~h}$ for the first while it was $10.5 \mathrm{~h}$ and ranged between $7-12 \mathrm{~h}$ for the second. Concerning the combination of zinc phosphide $0.125 \%+$ Spasmomen $0.1 \%$ or $0.05 \%$, both combinations gave the same mortality percentage $75 \%$. But there was considerable variation in the average time to death where it was $15 \mathrm{~h}$ and ranged between $12-24 \mathrm{~h}$ for the first combination and $17 \mathrm{~h}$ with wide range $6-24 \mathrm{~h}$ for the second mixture. On the other side, the average bait consumption raised to $10.4 \mathrm{~g}$ in case of Spasmomen $0.05 \%$ comparing with $9.2 \mathrm{~g}$ for Spasmomen $0.1 \%$ when added to $0.125 \%$ zinc phosphide bait. From the previous results in Tables ( 1 and 2 ) it could be observed that Spasmomen at level 0.05 or $0.1 \%$ enhanced the mortality percentage from 50 to $75 \%$ when added to zinc phosphide bait at rate $0.125 \%$ with increasing the amount of bait intake from $4.8 \mathrm{~g}$ for zinc phosphide alone to reach $10.4 \mathrm{~g}$ in case of the same concentration of zinc phosphide mixed with $0.05 \%$ Spasmomen. Also, the range of time to death was shorter (6-24h) with mean of $17.0 \mathrm{~h}$ for zinc phosphide alone than (12-24h) and average $18 \mathrm{~h}$ for the combination, respectively. Metwally (2005) found that addition of $0.001 \%$ Librax drug increased the average consumption of bait treated and untreated with zinc phosphide. Asran (1994) recorded that in free and non- choice feeding tests on Arvicanthis niloticus, $1.0 \%$ zinc phosphide bait gave 80 and $90 \%$ mortality.

\section{1-2 Free- Choice Feeding Test}

The response of albino rat to Spasmomen alone or mixed with zinc phosphide bait under free- choice conditions was shown in Table (3). Regarding the treatment of Spasmomen alone, data revealed that animals accepted on Spasmomen $0.05 \%$ more than the same compound when used at $0.1 \%$ whereas the acceptability percentage was $51.6 \%$ for the lowest concentration of Spasmomen while it was $48.7 \%$ in case of the highest concentration. On the other hand, Spasmomen at rate $0.05 \%$ when added to zinc phosphide bait at 0.25 and $0.125 \%$ enhanced the acceptance to 43.5 and $46.3 \%$ comparing with 6.1 and $10.2 \%$ for zinc phosphide alone, respectively. The 
palatability increased with decrease of zinc phosphide concentration. Zinc phosphide at 0.125 and $0.25 \%$ achieved only 25 and $50 \%$ mortality while mixing of $0.05 \%$ Spasmomen with the same concentrations of zinc phosphide enhanced the mortality to 50 and $75 \%$, respectively. Mortality percentage increased with increasing zinc phosphide concentration. The opposite occurred with time to death as it reduced from $20 \mathrm{~h}$ with range $18-24 \mathrm{~h}$ in case of low concentration to $18 \mathrm{~h}$ and range $12-24 \mathrm{~h}$ for the high concentration of zinc phosphide bait. Metwally (2005) found that the acceptability of roof rat Rattus rattus to zinc phosphide bait $1.0 \%$ increased with addition of $0.001 \%$ librax drug by $4.7 \%$ while mortality percentage was $100 \%$ for both. El- Deeb et al (1991) stated that zinc phosphide bait shyness could be solved with Nile rat Arvicanthis niloticus with changing preferred baits and additives.

\section{2- Field Studies}

The efficiency of zinc phosphide bait alone at 0.25 and $0.125 \%$ and mixed with Spasmomen $0.05 \%$ was tested against wild Norway rat, $R$. norvegicus under field conditions. Data in Table (4) show that the combination of zinc phosphide $0.25 \%+$ Spasmomen was the most effective one as it gave $71.2 \%$ rat-population reduction followed by $66.0 \%$ for zinc phosphide $0.25 \%$ alone and $56.0 \%$ for the mixture of zinc phosphide $0.125 \%+$ Spasmomen while zinc phosphide $0.125 \%$ alone came in the last rank as it caused only $17.4 \%$ population reduction. On the other hand, mixing of $0.05 \%$ Spasmomen enhanced the consumed amount of zinc phosphide bait from 350 to $424 \mathrm{~g}$ and from 401 to $470 \mathrm{~g}$ for the two concentrations of zinc phosphide, respectively. Reviewing the aforementioned results, it is obvious that the field performance was in harmony with laboratory results. Meehan (1984) stated that Norway rat is the most wary feeder and affected by neophobia. El- Deeb et al. (2007) suggested that the longest bait shyness period to zinc phosphide was recorded with Norway rat between the different rodent species.

Discussing the previous data, it could be concluded that the antispasmodic action of Spasmomen drug prevent the pain resulting from zinc phosphide treatment under laboratory and field conditions. This action lead rats to accept the bait of zinc phosphide and eat more. These result was confirmed during the laboratory studies as no spasmodic effects or pain were observed on the animals treated with Spasmomen when added to zinc phosphide comparing with those treated with zinc phosphide alone. Richard and Pamela (2000) and Sweetman (2002) mentioned that the antispasmodic drugs has effect on the symptomatic treatment of gastrointestinal spam or discomfort of the gastrointestinal tract that may be associated with spam of smooth muscles of the gut. 
ENHANCING THE EFFICIENCY OF ZINC PHOSPHIDE BATT USING ANTISPASMODIC AGENT (OCTYLONIUM BROMIDE) AGAINST ALBINO AND WILD NORWAY RATS

Table 1. Effect of different concentrations of zinc phosphide bait against albino rat using non choice feeding test.

\begin{tabular}{|c|c|c|c|c|}
\hline \multirow{2}{*}{$\begin{array}{l}\text { Concentration of } \\
\text { zinc ph. Bait \% }\end{array}$} & \multirow{2}{*}{$\begin{array}{c}\text { Average bait } \\
\text { consumption } \\
\text { (g) }\end{array}$} & \multirow{2}{*}{$\%$ Mortality } & \multicolumn{2}{|c|}{ Time to death (h) } \\
\hline & & & Mini - Max. & Mean \\
\hline 0.5 & . $\quad 4.1$ & $\therefore \quad 100$ & $6-12$ & 9 \\
\hline 0.25 & 4.3 & 100 & $12-24$ & 15 \\
\hline 0.125 & 4.8 & 50 & $12-24$ & 18 \\
\hline 0.0625 & 5.0 & 0.0 & 0.0 & $0 . \dot{0}$ \\
\hline \multicolumn{2}{|c|}{ L.S.D } & 27.8 & & \\
\hline
\end{tabular}

Table 2. Response of albino rat to zinc phosphide bait mixed with Spasmomen drug using non- choice feeding test.

\begin{tabular}{|c|c|c|c|c|}
\hline \multirow[b]{2}{*}{ Treatment } & \multirow{2}{*}{$\begin{array}{c}\text { Average bait } \\
\text { consumption }(\mathrm{g})\end{array}$} & \multirow[b]{2}{*}{$\%$ Mortality } & \multicolumn{2}{|c|}{ Time to death (h) } \\
\hline & & & $\begin{array}{l}\text { Mini - } \\
\text { Max }\end{array}$ & Mean \\
\hline $\begin{array}{l}\text { Zinc ph. } 0.25 \%+ \\
\text { Spasmomen } 0.1 \%\end{array}$ & 6.7 & $\begin{array}{r}100 \\
\therefore \quad . \\
\end{array}$ & $6-12$ & 9 \\
\hline $\begin{array}{c}\text { Zinc ph. } 0.125 \% \\
+ \text { Spasmomen } 0.1 \%\end{array}$ & 9.2 & 75 & $12-24$ & 15 \\
\hline $\begin{array}{l}\text { Zinc ph. } 0.25 \%+ \\
\text { Spasmomen } 0.05 \%\end{array}$ & 7.0 & 100 & $7-12$ & 10.5 \\
\hline $\begin{array}{c}\text { Zinc ph. } 0.125 \% \\
\text { +Spasmomen } \\
0.05 \%\end{array}$ & 10.4 & 75 & $6-24$ & 17.0 \\
\hline L.S. & - & 15.3 & & \\
\hline
\end{tabular}


Table 3. Effect of Spasmomen drug on the acceptance of zinc phosphide bait to albino rat using free- choice feeding test.

\begin{tabular}{|c|c|c|c|c|}
\hline \multirow{2}{*}{ Treatment } & \multirow{2}{*}{$\%$ Acceptance } & \multirow{2}{*}{$\%$ Mortality } & \multicolumn{2}{|c|}{ Time to death (h) } \\
\hline & & & Mini - Max & Mean \\
\hline Spasmomen $0.1 \%$ & 48.7 & 0.0 & 0.0 & 0.0 \\
\hline $\begin{array}{l}\text { Spasmomen } \\
0.05 \%\end{array}$ & 51.6 & 0.0 & 0.0 & 0.0 \\
\hline Zinc ph. $0.25 \%$ & 6.1 & 50 & $12-24$ & 16.5 \\
\hline $\begin{array}{c}\text { Zinc ph. } 0.25 \%+ \\
\text { Spasmomen } \\
0.05 \% \\
\end{array}$ & 43.5 & 75 & $12-24$ & 18 \\
\hline Zinc ph. $0.125 \%$ & 10.2 & 25 & $12-24$ & 18.5 \\
\hline $\begin{array}{c}\text { Zinc ph. } 0.125 \%+ \\
\text { Spasmomen } \\
0.05 \% \\
\end{array}$ & 46.3 & 50 & $18-24$ & 20 \\
\hline L.S & & 10.5 & & \\
\hline
\end{tabular}

Table 4. Efficacy of zinc phosphide bait mixed with $0.05 \%$ Spasmomen drug against Norway rat Rattus norvegicus under field conditions.

\begin{tabular}{|l|c|c|c|c|}
\hline \multirow{2}{*}{ Treatment } & \multicolumn{3}{|c|}{ Bait consumption (g) } & \multirow{2}{*}{$\begin{array}{c}\text { \%Population } \\
\text { reduction }\end{array}$} \\
\cline { 2 - 5 } & Pre-treatment & Treatment & $\begin{array}{r}\text { Post- } \\
\text { treatment }\end{array}$ & \\
\hline Zinc ph. 0.25\% & 642 & 350 & 218 & 66.0 \\
\hline $\begin{array}{l}\text { Zinc ph. } \\
0.025 \%+ \\
\text { Spasmomen }\end{array}$ & 565 & 424 & 163 & 71.2 \\
\hline $\begin{array}{l}\text { Zinc ph. } \\
0.125 \%\end{array}$ & 593 & 401 & 490 & 17.4 \\
\hline $\begin{array}{l}\text { Zinc ph. } \\
0.125 \%+ \\
\text { Spasmomen }\end{array}$ & 482 & 470 & 212 & 56.0 \\
\hline \multicolumn{2}{|c|}{} & L.S.D. & & 5.2 \\
\hline
\end{tabular}




\section{REFERENCES}

1. Asran, A. A. 1994. Susceptibility and palatability of some Egyptian rodent to zinc phosphide. Egypt. J. Agric. Res., 72 (1): 141-145.

2. El- Deeb, H. I., M. A. Abdalla, M. A. Kandil and W. M. Gabr. 1991. Laboratory and Field studies on overcome zinc phosphide bait shyness in relation to some rodent species. Fourth Arab Congress of Plant Protection. Cairo 1- 5 December.

3. El- Deeb, H. I., A. M. Metwally, M. H. Mowafi, W. M. Gäabr and A. E. Al- Wakeel. 2007. Determination the periods of bait shyness to zinc phosphide in different rodent species. Egypt. J. Agric. Res., 85 (3): 809- 883.

4. Gabr, W. M., Fatma K. Khidr and A. M. Hegab. 2004. Evaluation of Oshar crude plant extract as a rodenticide under laboratory and field conditions Zagazig. J. Agric Res., 13 (4A), 1607- 1616.

5. Meehan, A. P. 1984. Rats and mice, their biology and control, the rentokil library, London.

6. Metwally, F. M. 2005. Ecological study of rodents infesting agricultural areas and new control approaches. M. Sc. Thesis. Institute of Environ. Studies and Res. Ain Shams University.

7. Palmateer, S. D. 1974. Laboratory testing of albino rats with anticoagulant rodenticides. Proc. 6th Vert. Pest Conf. Anaheium. Calif. March 5-7, 63- 72.

8. Prakash, I. 1988. Bait shyness of two gerbils, Tetra indica and Meriones hurrianae. Ann. Appl. Biol., 69, 161- 172.

9. Rennison, B. D. 1977. Methods of testing rodenticides in the field against rats. J. Pestic. Sci., 8: 405- 413.

10. Richard, A. H. and V. C. Pamela. 2000. Lippincott illustrated reviews in pharmacology.

11. Sweetman, S. C. 2002. Martindale, The complete drug reference. Thirty third edition 2002, Publications division of pharmaceutical society of Great Britain. 
رفع كفاءة طعم فوسقيد الزنك باستخدام عقار أوكتيلونيوم بروميد كمسكن للألم ضد

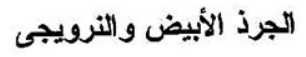

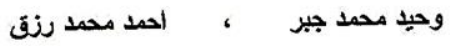

$$
\text { معهد بحوث وقاية النباتات- مركز البحوث الزراعية - جبزة }
$$

أجريت بعض التجارب المعملية والحقلية لرفع كفاءة طعم فوسفيد الزنك ضد الفئران باستخدام

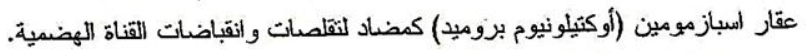

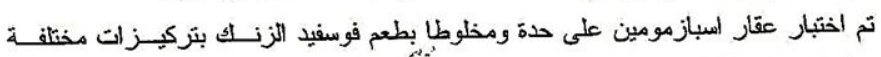

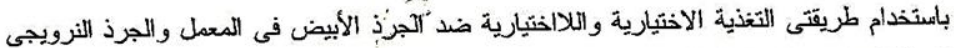
فى الحقل فى مركز الو اسطى بمحافظة بنى سويف.

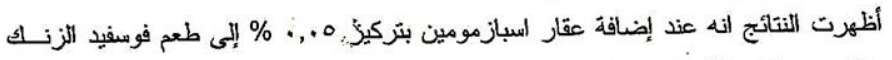

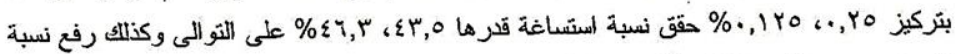

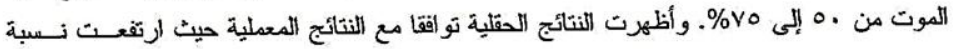

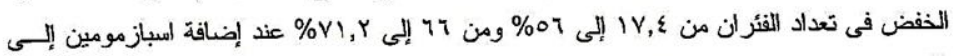

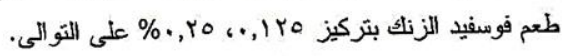

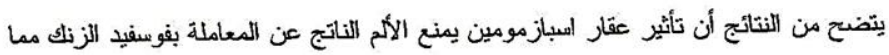

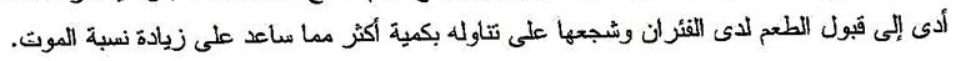

